\title{
EKSPERIMENTASI MODEL PEMBELAJARAN \\ KOOPERATIF TIPE TWO STAY TWO STRAY DENGAN PENDEKATAN SAINTIFIK (TSTS-PS) DAN TIPE TEAMS ASSISTED INDIVIDULIZATION DENGAN PENDEKATAN SAINTIFIK (TAI-PS) PADA MATERI HIMPUNAN DITINJAU DARI KECEMASAN BELAJAR MATEMATIKA SISWA KELAS VII SMP NEGERI SE-KABUPATEN KARANGANYAR
}

\author{
Ratnasari $^{1}$, Mardiyana ${ }^{2}$, Budi Usodo ${ }^{3}$ \\ ${ }^{1,2,3}$ Prodi Magister Pendidikan Matematika, FKIP Universitas Sebelas Maret Surakarta
}

\begin{abstract}
This research aimed to find out: (1) which one is better among cooperative learning models of TSTS with scientific approach (TSTS-PS), TAI with scientific approach (TAI-PS) or classical with scientific approach one in giving mathematics learning achievement, (2) which one is better among students' anxiety categories, students having high, middle or low categories giving mathematics learning achievement. (3) in each learning model, which one is better among students' anxiety categories in giving mathematics learning achievement and (4) in each anxiety categories, which one is better among TSTS with scientific approach (TSTS-PS), TAI with scientific approach (TAI-PS) or classical with scientific approach in giving mathematics learning achievement. This research was the quasi-experimental research with $3 \times 3$ factorial design. The population of research was all grade VII students of Junior High School (SMP) in Karanganyar Regency. The samples were chosen by using stratified cluster random sampling. The instruments that were used to collect the data were the test of mathematics achievement and questionnaire of students' anxiety categories. Prior knowledge data are examined by using one-way ANOVA with unbalanced cells. It shows that three classes have balance prior knowledge. Meanwhile, the technique of analyzing the data was two-ways ANOVA with unbalanced cells. The result of research showed as follows. (1) The TSTS-PS had better learning achievement than the TAI-PS and classical with scientific approach. TAI-PS had learning achievement as good as the classical with scientific approach, (2) The students having low anxiety categories had better learning achievement than those having middle and high categories. The students having middle anxiety categories had learning achievement as good as those having high categories. (3) In each learning models, the students having low anxiety categories had better learning achievement than those having middle and high categories. The students having middle anxiety categories had learning achievement as good as those having high categories. (4) In each of students' anxiety categories, the TSTS with scientific approach had better learning achievement than the TAI and classical with scientific approach. TAI with scientific approach had learning achievement as good as the classical with scientific approach.
\end{abstract}

Keywords : Two Stay Two Stray (TSTS), Teams Assisted Individulization (TAI), Classical, Scientific Approach, Students' Anxiety.

\section{PENDAHULUAN}

Di era globalisasi ini guru dituntut bekerja cepat untuk bersaing di tataran internasional dalam pengembangan ilmu dan teknologi. Dampak dari kemajuan IPTEK mengakibatkan perubahan di berbagai bidang kehidupan. Semua perkembangan tidak lepas dari pendidikan. Oleh karena itu, yayasan dan Lembaga penyelenggara pendidikan Indonesia dituntut untuk berperan aktif dalam meningkatkan sumber daya saing tinggi. 
Untuk itu, mutu dan kualitas pendidikan harus segera diperbaiki sehingga tujuan pembelajaran dapat tercapai secara optimal.

Pada saat ini kurikulum yang diterapkan adalah kurikulum 2013. Kurikulum 2013 menekankan pada dimensi pedagogik modern dalam pembelajaran, yaitu menggunakan pendekatan ilmiah. Pendekatan ilmiah dalam pembelajaran sebagaimana dimaksud meliputi mengamati, menanya, mencoba, menalar, dan mengkomunikasikan. Selain itu juga, dalam proses pembelajarannya siswa dituntut untuk dapat menyelidiki fenomena atau gejala, memperoleh pengetahuan baru, dan memadukan dengan pengetahuan sebelumnya. Sehingga diharapkan melalui pendekatan ini siswa memiliki kompetensi sikap, keterampilan dan pengetahuan jauh lebih baik.

Proses pembelajaran dan prestasi belajar matematika di Indonesia sampai saat ini belum mengalami perubahan yang baik secara signifikan. Hal ini terbukti dari data hasil UN tahun ajaran 2012/2013, nilai rata-rata UN matematika SMP Negeri tingkat nasional masih tergolong rendah dibandingkan dengan mata pelajaran lainnya yaitu 5,57.

Menurut Erman Suherman, dkk (2003: 58), ada beberapa tujuan pembelajaran matematika SMP, diantaranya adalah siswa memiliki keterampilan matematika sebagai peningkatan dan perluasan dari matematika sekolah dasar untuk dapat digunakan dalam kehidupan sehari-hari. Matematika adalah dasar dari ilmu pengetahuan, karena matematika mempunyai daya abstraksi yang mampu mengabstraksikan permasalahanpermasalahan yang sering muncul baik dalam matematika itu sendiri maupun dalam kehidupan sehari-hari, sehingga mampu menyelesaikan permasalahan-permasalahan dengan tepat dan cepat. Selain itu, matematika merupakan ilmu yang bersifat hierarkis, yaitu konsep satu dengan konsep lainnya ada kaitannya. Dalam matematika terdapat konsep atau topik prasyarat sebagai dasar untuk memahami konsep atau topik selanjutnya. Oleh karena itu, siswa sering mengalami kesulitan dalam pembelajaran matematika, bahkan ada beberapa siswa yang takut akan matematika. Mereka menganggap bahwa matematika adalah pelajaran yang sulit, karena matematika bersifat abstrak. Perasaan ini sering disebut dengan kecemasan belajar matematika. Menurut Yuksel-Sahim (2008) bahwa "Despite its importance, in daily life, mathematics is often viewed as a difficult topic. Such perpection is in part, due to the nature of math. However, it also has to do with preconceived notions about mathematics (Umay, 1996) and the anxiety individuals have for mathematics". Hal tersebut dapat diartikan bahwa meskipun penting, dalam kehidupan sehari-hari, matematika sering dipandang topik yang sulit. Pandangan seperti itu adalah sebagian dikarenakan sifat dari matematika. Namun, juga harus dilakukan dengan praduga tentang matematika dan kecemasan seseorang yang dimiliki untuk matematika. 
Kecemasan belajar matematika terjadi karena pengalaman siswa terdahulu, sehingga sulit untuk dihilangkan. Kecemasan siswa yang berlebihan akan mengakibatkan seorang siswa mengalami kegagalan-kegagalan yang menyebabkan ia menjadi pesimis, mempunyai harga diri kurang, putus asa, frustasi, tak dapat bertindak efektif dan tidak dapat mencapai prestasi optimal. Kecemasan belajar matematika siswa harus menjadi perhatian bagi guru. Karena dengan kecemasan belajar matematika tinggi, siswa akan terhambat dalam mengikuti pembelajaran matematika.

Berdasarkan penelitian yang dilakukan Pourmeslemi, et al (2013:4) menunjukkan bahwa terdapat hubungan yang signifikan antara tingkat kecemasan matematika yang tinggi dan prestasi belajar. Hal ini juga senada dengan penelitian yang dilakukan oleh Nadeem., et al (2012 : 526) menunjukkan bahwa tingkat kecemasan meningkat maka prestasi belajar menurun pada siswa laki-laki maupun perempuan. Oleh karenanya diperlukan strategi atau alternatif penanganan yang tepat untuk mengurangi kecemasan siswa tersebut sehingga tidak memberikan dampak yang lebih luas lagi terhadap prestasi belajar siswa.

Berbagai upaya untuk tercapainya proses pembelajaran yang baik dan meningkatkan prestasi belajar matematika adalah pembaharuan kurikulum, pengembangan model pembelajaran, sarana dan prasarana pembelajaran, dan sebagainya. Pengembangan model pembelajaran merupakan unsur yang paling penting dalam mencapai tujuan tersebut. Berdasarkan wawancara dengan beberapa guru matematika, kegiatan pembelajaran yang berlangsung di dalam kelas cenderung teacher centered. Proses pembelajaran masih kurang diperhatikan. Hal ini dapat menghambat aktivitas siswa dalam pembelajaran matematika, bahkan terkadang siswa merasa tidak yakin atau tidak mampu dalam menyelesaikan masalah yang muncul. Padahal, untuk tercapainya tujuan pembelajaran matematika di SMP, pembelajaran harus dilaksanakan dengan sebaik-baiknya untuk memperoleh hasil maksimal. Oleh karena itu, penting untuk mengembangkan suatu model pembelajaran yang mampu meningkatkan prestasi belajar matematika.

Model pembelajaran kooperatif merupakan salah satu model yang dapat mengajak siswa untuk aktif dalam pembelajaran dibandingkan dengan model pembelajaran klasikal. Hal ini senada dengan pendapati Ozsoy dan Yildiz (2004) bahwa :

Cooperative learning method is a strong base for learning. In cooperative learning method, the students learn driving logic mathematically, sharing their opinions with the others, and using math for solving the problems. During the research most of the students wanted to use cooperative learning method at the other lessons too. In the math teaching, cooperative learning method is a good choice for learning effectively. 
Model pembelajaran kooperatif adalah dasar yang kuat untuk belajar. Dalam model pembelajaran kooperatif, siswa belajar menggerakkan logika secara matematis, berbagi pendapat mereka dengan yang lainnya, dan menggunakan matematika untuk memecahkan masalah. Model pembelajaran kooperatif diantaranya model pembelajaran kooperatif tipe TSTS dan TAI.

Menurut Trianto (2007), model pembelajaran kooperatif tipe TSTS merupakan model pembelajaran yang menuntut siswa untuk aktif. Model ini menggunakan kelompok-kelompok kecil dengan jumlah anggota tiap kelompok 4-5 orang siswa secara heterogen, diawali dengan penyampaian tujuan pembelajaran, penyampaian materi, kegiatan kelompok, kuis, dan penghargaan kelompok. Model pembelajaran kooperatif tipe TSTS juga memberikan kesempatan kepada siswa untuk bertukar pikiran dan membangun keterampilan sosial seperti mengajukan pertanyaan dan memberi kesempatan kepada siswa untuk belajar dengan cara siswa mengunjungi/bertamu antar kelompok untuk berbagi informasi, yaitu siswa yang tinggal bertugas memberikan informasi mereka ke kelompok lain tentang hasil diskusi kelompoknya, sedangkan siswa yang bertamu bertugas untuk mencatat penjelasan hasil diskusi kelompok yang dikunjungi serta bertanggungjawab menjelaskan hasil informasi yang diperoleh dari bertamu kepada kelompoknya, sehingga siswa dilatih untuk berbagi dan tidak hanya mampu bekerja secara individu. Hal ini sesuai dengan pendapat Hammiddy (2010 : 12) bahwa :

One strategy that can be applied in teaching poetry is cooperative learning strategy because besides cooperative learning is as an effective instructional method, it is also aa successful way to enhance social and academic development among students. TS-TS will work well if students have a product or informatioan to share. TS-TS strategy essentially is a group discussion model. Each member of group has its own responsibilities (two students become 'strayers' and other two students become'stayers')".

Berdasarkan kutipan di atas, diperoleh bahwa strategi yang efektif untuk meningkatkan kemampuan akademik adalah dengan pembelajaran kooperatif. Hal ini juga memberikan pengalaman siswa dalam mengumpulkan informasi dan melaporkan kembali ke rekan satu tim mereka. TS-TS dasarnya adalah model diskusi kelompok. Setiap anggota kelompok memiliki tanggung jawab sendiri (dua anggota menjadi 'strayers' dan dua anggota menjadi “stayers'). Sedangkan model pembelajaran kooperatif tipe TAI merupakan model pembelajaran kooperatif dengan menempatkan pembelajaran kelompok-kelompok kecil, untuk setiap kelompok beranggotakan 4 sampai 5 siswa yang heterogen, baik dalam hal jenis kelamin, ras, tingkat kemampuan untuk menyelesaikan tugas kelompok yang sudah disiapkan guru. Siswa yang pandai dapat 
membantu temannya sehingga akan semakin terasah kemampuannya dan siswa yang lemah akan terbantu dalam memahami materi oleh siswa yang pandai.

Tujuan dari penelitian ini untuk mengetahui manakah yang : (1) memberikan prestasi belajar yang lebih baik, model pembelajaran kooperatif tipe two stay two stray dengan pendekatan saintifik (TSTS-PS), model pembelajaran kooperatif tipe teams assisted individulization dengan pendekatan saintifik (TAI-PS) atau model pembelajaran klasikal dengan pendekatan saintifik. (2) memberikan prestasi belajar yang lebih baik, siswa yang memiliki tingkat kecemasan belajar matematika rendah, sedang atau tinggi. (3) memberikan prestasi belajar yang lebih baik pada masing-masing model pembelajaran pada masing-masing tingkat kecemasan belajar matematika. (4) memberikan prestasi belajar lebih baik pada masing-masing tingkat kecemasan belajar matematika pada masing-masing model pembelajaran.

\section{METODE PENELITIAN}

Penelitian ini dilaksanakan pada SMP Negeri di Kabupaten Karanganyar, dengan subyek penelitian adalah siswa SMP kelas VII semester ganjil tahun pelajaran 2014/2015. Sampelnya diambil dengan teknik stratified cluster random sampling. Penelitian dilakukan di SMP Negeri 1 Kebakkramat, SMP Negeri 2 Jaten, SMP Negeri 2 Matesih yang masing-masing diambil tiga kelas eksperimen. Sampel dalam penelitian ini berjumlah 262 siswa yang terdiri dari 97 siswa pada kelas eksperimen satu, 89 siswa pada kelas eksperimen dua dan 76 siswa pada kelas kontrol. Jenis penelitian ini adalah penelitian eksperimental semu dengan rancangan faktorial 3 x 3 .

Dalam penelitian ini terdapat dua variabel bebas yaitu model pembelajaran dan kecemasan belajar matematika siswa dan satu variabel terikat yaitu prestasi belajar matematika. Pengumpulan datanya menggunakan metode tes, dokumentasi dan angket. Metode dokumentasi digunakan untuk mengumpulkan data kemampuan awal siswa, metode tes digunakan untuk mengumpulkan data prestasi belajar siswa dan metode angket digunakan untuk mengumpulkan data kecemasan belajar matematika siswa.

Sebelum melakukan penelitian, terlebih dahulu dilakukan uji keseimbangan kemampuan awal siswa dengan uji analisis variansi satu jalan. Untuk melakukan uji analisis variansi satu jalan, terlebih dahulu melakukan uji prasyarat untuk anava yaitu uji normalitas populasi dengan metode Lilliefors dan uji homogenitas variansi populasi dengan uji Bartlett. Pengujian hipotesis penelitian, menggunakan teknik analisis variansi dua jalan dengan banyaknya baris 3 dan banyaknya kolom 3 dengan sel tak sama. Sebelum melakukan analisis variansi dua jalan terlebih dahulu melakukan uji prasyarat untuk anava yaitu uji normalitas dengan metode Lilliefors dan uji homogenitas dengan uji 
Bartlett. Jika diperlukan uji lanjut digunakan uji lanjut pasca analisis variansi dengan metode Scheffe (Budiyono, 2009: 168).

\section{HASIL PENELITIAN DAN PEMBAHASAN}

Hasil uji keseimbangan terhadap data kemampuan awal siswa diperoleh bahwa ketiga populasi mempunyai kemampuan awal yang sama. Setelah eksperimen, didapatkan data prestasi belajar matematika. Rerata prestasi belajar pada masing-masing sel dan rerata marginal dapat dilihat pada Tabel 1.

Tabel 1. Rangkuman Rerata Sel dan Rerata Marginal

\begin{tabular}{ccccc}
\hline \multirow{2}{*}{ Model Pembelajaran } & \multicolumn{2}{c}{ Kecemasan Belajar Matematika } & \multirow{2}{*}{ Rerata } \\
\cline { 2 - 4 } & Tinggi & Sedang & Rendah & Marginal \\
\hline TSTS-PS & 67,5555 & 71,8571 & 80,2500 & 73,4712 \\
TAI-PS & 61,1429 & 59,6190 & 64,3870 & 61,7931 \\
Klasikal & 56,8000 & 58,7878 & 73,2000 & 60,9090 \\
Rerata Marginal & 61,3608 & 63,1219 & 72,3855 & - \\
\hline
\end{tabular}

Sebelum dilakukan analisis variansi dua jalan, terlebih dahulu dilakukan uji prasyarat yaitu uji normalitas dan uji homogenitas. Berdasarkan uji normalitas, dapat diketahui bahwa sampel berasal dari populasi yang berdistribusi normal. Berdasarkan pada uji homogenitas dapat diketahui bahwa data pada masing-masing model pembelajaran dan kecemasan belajar matematika siswa mempunyai variansi yang homogen.

Selanjutnya dilakukan uji analisis variansi dua jalan dengan sel tak sama. Rangkuman uji analisis variansi disajikan pada Tabel 2.

Tabel 2. Rangkuman Analisis Variansi Dua Jalan

\begin{tabular}{ccccccc}
\hline Sumber & $\mathrm{JK}$ & $\mathrm{dk}$ & $\mathrm{RK}$ & $\mathrm{F}_{\mathrm{obs}}$ & $F_{\alpha}$ & Keputusan \\
\hline $\begin{array}{c}\text { Model } \\
\text { Pembelajaran }\end{array}$ & 6714,9949 & 2 & 3357,4975 & 13,0445 & 3,00 & $\mathrm{H}_{\mathrm{OA}}$ ditolak \\
Kecemasan & 5691,3644 & 2 & 2845,6822 & 11,0560 & 3,00 & $\mathrm{H}_{\mathrm{OB}}$ ditolak \\
Belajar (B) & & & & & & \\
Interaksi (AB) & 1463,0417 & 4 & 365,7604 & 1,4211 & 2,37 & $\mathrm{H}_{\mathrm{OAB}}$ diterima \\
Galat & 65119,0033 & 253 & 257,3874 & - & - & - \\
Total & 78988,4044 & 261 & - & - & - & - \\
\hline
\end{tabular}

Berdasarkan Tabel 2 dapat disimpulkan sebagai berikut: (a) Terdapat perbedaan prestasi belajar matematika antara ketiga model pembelajaran. (b) Terdapat perbedaan prestasi belajar matematika antara ketiga kategori kecemasan belajar matematika siswa. (c) Tidak terdapat interaksi antara model pembelajaran dengan kategori kecemasan belajar matematika siswa terhadap prestasi belajar matematika.

Dari hasil perhitungan anava diperoleh bahwa $\mathrm{H}_{\mathrm{OA}}$ ditolak sehingga perlu dilakukan uji lanjut pasca analisis variansi dengan metode Scheffe' untuk uji komparasi antar baris. 
Rangkuman perhitungan uji lanjut rerata antar baris disajikan pada Tabel 3.

Tabel 3. Rangkuman Hasil Uji Komparasi Ganda Antar Baris

\begin{tabular}{cccc}
\hline $\mathrm{H}_{0}$ & $\mathrm{~F}_{\text {obs }}$ & $\mathrm{F}_{\text {tabel }}$ & Keputusan Uji \\
\hline$\mu_{1}=\mu_{2}$ & 23,0489 & 6,00 & $\mathrm{H}_{0}$ ditolak \\
$\mu_{1}=\mu_{3}$ & 25,8677 & 6,00 & $\mathrm{H}_{0}$ ditolak \\
$\mu_{2}=\mu_{3_{\mathrm{a}}}$ & 0,0737 & 6,00 & $\mathrm{H}_{0}$ diterima \\
\hline
\end{tabular}

Berdasarkan Tabel 1 dan Tabel 3 hasil uji komparasi antar baris pada masing-masing model pembelajaran, diperoleh simpulan bahwa: (1) prestasi belajar siswa yang dikenai model pembelajaran TSTS-PS lebih baik daripada prestasi siswa yang dikenai model pembelajaran TAI-PS, (2) prestasi belajar siswa yang dikenai model pembelajaran TSTSPS lebih baik daripada prestasi siswa yang dikenai model pembelajaran Klasikal, (3) prestasi belajar matematika siswa yang dikenai model pembelajaran kooperatif tipe TAIPS sama baiknya dengan model pembelajaran Klasikal.

Hal ini sesuai dengan penelitian yang dilakukan oleh Fitriana Anggar Kusuma (2014) bahwa model pembelajaran tipe TSTS memberikan prestasi belajar lebih baik daripada model pembelajaran Langsung. Ini dikarenakan selama proses penelitian model pembelajaran tipe TSTS-PS para siswanya dikelompokkan menjadi beberapa kelompok yang terdiri dari empat atau lima anggota. Setiap anggota kelompok saling aktif berbagi informasi mengenai materi yang sedang dibahas dengan cara saling mengunjungi atau bertamu. Pada saat bertamu, siswa menyampaikan hasil diskusi kelompoknya dan mencari informasi tentang apa yang belum dapat dikerjakan kelompoknya dari kelompok lain, begitu juga untuk siswa yang tinggal dikelompok, mereka harus menjelaskan apa yang akan ditanyakan tamu dari kelompok lain. Dengan adanya tahap ini, para siswa dapat memperoleh informasi lebih banyak dari pembelajaran tersebut. Lain halnya dengan model pembelajaran kooperatif tipe TAI-PS, walaupun para siswanya dibentuk secara kelompok yang membuat siswa saling aktif, tetapi para siswa hanya memperoleh informasi dari anggota kelompoknya saja, tidak dari anggota kelompok lainnya.

Dari hasil perhitungan anava diperoleh bahwa $\mathrm{H}_{\mathrm{OB}}$ ditolak sehingga perlu dilakukan uji lanjut pasca analisis variansi dengan metode Scheffe' untuk uji komparasi antar kolom. Rangkuman perhitungan uji lanjut rerata antar kolom disajikan pada Tabel 4.

Tabel 4. Rangkuman Hasil Uji Komparasi Ganda Antar Kolom

\begin{tabular}{cccc}
\hline $\mathrm{H}_{0}$ & $\mathrm{~F}_{\mathrm{obs}}$ & $\mathrm{F}_{\text {tabel }}$ & Keputusan Uji \\
\hline$\mu_{\mathrm{s}_{1}=\mu_{\mathrm{n}}}$ & 0,7632 & 6,00 & Ho diterima \\
$\mu_{\cdot 1}=\mu_{\cdot 3}$ & 22,0549 & 6,00 & Ho ditolak \\
$\mu_{\cdot 2}=\mu_{\cdot 3}$ & 13,4557 & 6,00 & Ho ditolak
\end{tabular}

Berdasarkan Tabel 1 dan Tabel 4 hasil uji komparasi antar kolom pada masingmasing model pembelajaran, diperoleh simpulan bahwa: (1) siswa dengan kecemasan belajar matematika sedang dan siswa dengan kecemasan belajar matematika tinggi 
mempunyai prestasi belajar yang sama baik, (2) siswa dengan kecemasan belajar matematika rendah lebih baik daripada prestasi belajar matematika dengan kecemasan belajar matematika tinggi, (3) siswa dengan kecemasan belajar matematika rendah lebih baik daripada prestasi belajar matematika dengan kecemasan belajar matematika sedang.

Hal ini sesuai dengan hipotesis penelitian dan sejalan dengan penelitan yang dilakukan Anna Setyowati (2013) menyimpulkan bahwa siswa dengan kecemasan pada matematika rendah memiliki prestasi belajar matematika yang lebih baik dibandingkan siswa dengan kecemasan belajar matematika sedang. Hal itu dikarenakan pada siswa kecemasan belajar matematika rendah cenderung dapat menyelesaikan suatu selama proses pembelajaran walaupun terkadang menemui kesulitan dalam pelaksanaanya, tetapi pada akhirnya siswa dengan kecemasan belajar matematika rendah dapat menyelesaikan masalah tersebut dengan tepat. Lain halnya dengan siswa yang dengan kecemasan belajar matematika sedang cenderung pasif pada saat pembelajaran di kelas sehingga tidak dapat menyelesaikan suatu permasalahan yang dihadapi dalam pembelajaran dengan cepat dan tepat.

Berdasarkan anava dua jalan diperoleh hasil bahwa $\mathrm{H}_{0 \mathrm{AB}}$ diterima, ini berarti bahwa tidak ada interaksi antara masing-masing model pembelajaran dan kategori kecemasan belajar matematika siswa terhadap prestasi belajar matematika siswa. Untuk masingmasing model pembelajaran, kesimpulan dapat diambil dari rerata marginal pada Tabel 1, sehingga didapat siswa dengan kecemasan belajar matematika rendah memberikan prestasi belajar matematika yang lebih baik daripada siswa dengan kecemasan belajar matematika sedang maupun tinggi, sedangkan siswa dengan kecemasan belajar matematika sedang dan siswa dengan kecemasan belajar matematika tinggi memberikan prestasi belajar matematika yang sama baik.

Ketidaksesuaian dikarenakan pada saat terjadinya diskusi siswa dengan kecemasan belajar matematika tinggi dan sedang cenderung mampu menenangkan diri, sehingga dapat aktif dalam pembelajaran di kelas. Kemudian, jika ada sesuatu yang kurang dipahami siswa dengan kecemasan belajar matematika tinggi dan sedang, mereka aktif mencari tahu dengan bertanya pada guru dan juga temannya. Sehingga siswa dengan kecemasan belajar matematika tinggi dan sedang dapat menyelesaikan suatu permasalahan. Selain itu, pada saat dikenai model pembelajaran TAI-PS, siswa dengan kecemasan belajar matematika rendah mereka lebih mampu berperan aktif dan mempunyai semangat belajar yang tinggi, dan memanfaatkan kemampuannya untuk mencerna soal-soal yang ada pada LKS dengan baik. Oleh sebab itu, siswa dengan kecemasan belajar matematika rendah mampu mengatasi suatu permasalah dengan tepat. Akibatnya siswa dengan kecemasan belajar matematika rendah memberikan prestasi 
belajar matematika yang lebih baik daripada kecemasan belajar matematika sedang maupun tinggi, sedangkan siswa dengan kecemasan belajar matematika sedang dan siswa dengan kecemasan belajar matematika tinggi memberikan prestasi belajar matematika yang sama baik.

Kemudian pada masing-masing kecemasan belajar matematika siswa, model pembelajaran kooperatif tipe TSTS-PS memberikan prestasi belajar yang lebih baik daripada model pembelajaran kooperatif tipe TAI-PS dan Klasikal, sedangkan model pembelajaran kooperatif TAI-PS memberikan prestasi belajar yang sama baik dengan model pembelajaran Klasikal.

Ketidaksesuaian dengan hipotesis ini dikarenakan pada model pembelajaran kooperatif tipe TAI-PS terjadi interaksi antar anggota kelompok dan pemikiran individu dibuktikan dengan pengerjaan soal. Namun, pada kenyataannya pemikiran individu tersebut belum bekerja secara optimal dan mengakibatkan kesulitan siswa dalam memahami materi. Hal tersebut juga terjadi pada siswa dengan kecemasan belajar matematika sedang meskipun memiliki semangat belajar tinggi tetapi kurang optimal dalam proses pembelajaran sehingga kurang menguasai materi dan prestasi belajar menurun. Ketidaksesuaian selanjutnya ini dimungkinkan oleh pada pembelajaran TSTSPS terdapat salah satu tahap dimana peserta didik bertamu ke kelompok lain, dimana dalam hal ini peserta didik diharuskan untuk siap mencari informasi dan bertanya sebanyak-banyaknya kepada kelompok yang didatangi tentang hal yang belum diketahui dan bertanggung jawab melaporkanya pada saat kembali ke kelompok masing-masing. Sedangkan untuk peserta didik yang tinggal dalam kelompok, mereka harus benar-benar memahami hasil diskusi kelompoknya, karena mereka harus menjelaskan kepada tamu dari kelompok lain. Akibatnya siswa yang dikenai model pembelajaran tipe TSTS-PS lebih memahami materi dan lebih mempunyai banyak pilihan dalam menyelesaikan masalah.

\section{SIMPULAN DAN SARAN}

Berdasarkan hasil analisis data dan pembahasan yang telah dilakukan, maka dapat disimpulkan hasil penelitian sebagai berikut. (1) Prestasi belajar matematika siswa yang menggunakan pembelajaran kooperatif tipe TSTS-PS lebih baik daripada model pembelajaran kooperatif tipe TAI-PS, prestasi belajar matematika dengan menggunakan kooperatif tipe TSTS-PS lebih baik daripada pembelajaran Klasikal, dan model pembelajaran kooperatif tipe TAI-PS memiliki prestasi yang sama dengan model pembelajaran Klasikal. (2) Siswa dengan kecemasan belajar matematika rendah memiliki prestasi belajar yang lebih baik daripada siswa dengan kecemasan belajar matematika 
sedang maupun tinggi, dan siswa dengan kecemasan belajar matematika sedang memiliki prestasi yang sama baik dengan siswa yang memiliki kecemasan belajar matematika tinggi (3) Pada masing-masing model pembelajaran, prestasi belajar matematika siswa dengan kecemasan belajar matematika rendah lebih baik daripada siswa dengan kecemasan belajar matematika sedang maupun tinggi, dan prestasi belajar matematika siswa dengan kecemasan belajar matematika sedang sama baik dengan prestasi belajar siswa dengan kecemasan belajar matematika tinggi. (4) Pada masing-masing kategori kecemasan belajar matematika siswa, prestasi belajar matematika dengan menggunakan pembelajaran kooperatif tipe TSTS-PS lebih baik daripada model pembelajaran kooperatif tipe TAI-PS maupun model pembelajaran Klasikal, dan model pembelajaran kooperatif tipe TAI-PS memiliki prestasi yang sama dengan model pembelajaran Klasikal.

Berdasarkan simpulan hasil penelitian di atas, penulis dapat memberikan beberapa saran yang dirangkum sebagai berikut. (1) Guru disarankan menerapkan model pembelajaran TSTS-PS untuk pembelajaran di kelas terutama pada materi himpunan. Hal ini dikarenakan dengan menggunakan model pembelajaran TSTS yang dikolaborasikan dengan pendekatan Saintifik, siswa secara aktif akan mengkonstruksi pengetahuannya untuk menemukan konsep dari materi yang dipelajari, sehingga siswa akan memahami materi pelajaran dengan lebih baik, (2) Guru perlu memperhatikan tingkat kecemasan belajar siswa yang dapat mempengaruhi prestasi belajar siswa. Dengan mengetahui perbedaan karateristik tersebut, guru dapat memilih model pembelajaran yang efektif untuk diterapkan. Sedapat mungkin guru harus meminimalkan kecemasan belajar siswa agar siswa tidak merasa takut dan tertekan sehingga siswa dapat belajar secara rilek tetapi tetap serius, (3) para peneliti lain dapat meneruskan atau mengembangkan penelitian ini dengan penelitian-penelitian sejenis pada materi pokok yang lain atau dengan modelmodel pembelajaran lain yang lebih inovatif agar penelitian ini dapat dimanfaatkan secara luas dan lebih meningkatkan kualitas pembelajaran matematika khususnya dan pendidikan pada umumnya.

\section{DAFTAR PUSTAKA}

Anna Setyowati. 2013. Eksperimentasi model pembelajaran kooperatif tipe Teams Games Tournament (TGT) dan fan-n-pick pada prestasi belajar matematika ditinjau dari kecemasan pada matematika. Tesis. Surakarta : UNS.

Budiyono. 2009. Statistika Untuk Penelitian Edisi Ke-2. Surakarta: UNS Press.

Erman Suherman; Turmudi; Didi Suryadi; Tatang Herman; Suhendra; Sufyani Prabawanto; Nurjanah dan Ade Rohayati. 2003. Strategi Pembelajaran Matematika Kontemporer. Bandung: UPI. 
Fitriana Anggar Kusuma. 2014. Eksperimentasi Model pembelajaran kooperatif tipe two stay two stray (tsts) dan think-pair-share (tps) pada materi persamaan dan pertidaksamaan linear satu variabel ditinjau dari karakteristik cara berpikir siswa. Tesis. Surakarta : UNS.

Hammiddy, M. 2010. Improving Students' Comprehension of Poems Using Two Stay Two Stray Strategy. Journal of Social Sciences. Vol. 10. 316-318.

Nadeem, M; Ali, A; Maqbool; S dan Uzma Zaidi, S. 2012. Impact of Anxiety on the academic Achievment of Students Having Different Mental Abilities at University Level in Bahawalpur Pakistan. Journal of Education Sciences, Vol 4, No 3, 519-528.

Ozsoy, N, dan Yildiz, N. 2004. The Effect Of Learning Together Technique Of Cooperative Learning Methodon Students Achievment in Mathematics Teaching $7^{\text {th }}$ Class of Primary School. The Turkish Online Journal of Education Technology. Vol 3, No 3, 49-54.

Pourmoslemi, N; Erfani, N dan Fieoozfar, I. 2013 Mathematiics Anxiety, Mathematics Performance and Gender Differences among Undergraduate Studenst. International Journal Of Scientific and Research Publication, Vol 3, No 7, 1-6.

Trianto. 2007. Model-model Pembelajaran Inovatif Berorientasi Konstruktivistik. Jakarta : Prestasi Pustaka Publisher.

Yuksel-Sahim, F. 2008. Mathematics Anxiety Among $4^{\text {th }}$ and $5^{\text {th }}$ Grade Turkish Elementary School Students. International Electronic Journal of Mathematics Education. Vol 3, No 3, 179-192. 